\title{
A new non-isidiate Leptogium species with transverse septate ascospores from Southeastern Brazil
}

\author{
Kitaura $\mathbf{M J}^{1}$, Marcelli MP ${ }^{2}$, Hora BR $^{1}$ and Jungbluth $\mathbf{P}^{1}$ \\ ${ }^{1}$ UNESP, Instituto de Biociências, Depto de Botânica, Distrito de Rubião Jr., Caixa Postal 510, Botucatu/SP, CEP \\ 18618-970, Brazil \\ ${ }_{2}^{2}$ Instituto de Botânica, Núcleo de Pesquisa em Micologia, Caixa Postal 68041, São Paulo/SP, CEP 04045-972, Brazil.
}

Kitaura MJ, Marcelli MP, Hora BR, Jungbluth P 2013 - A new non-isidiate Leptogium species with transverse septate ascospores from Southeastern Brazil. Mycosphere 4(5), 986-992, Doi $10.5943 /$ mycosphere/4/5/11

\begin{abstract}
A non-isidiate Leptogium species with transverse septate ascospores is described as new. The species was collected in Serra da Mantiqueira and initially identified as L. megapotamicum, but the study of the type specimen demonstrated differences in the tissues of the apothecia, which supported the observed morphological variations of the thalli and apothecia found by our descriptive protocol.
\end{abstract}

Key words - amphithecia - columnar hyphae - section Leptogiopsis - subhymenial tissue

\section{Introduction}

The gelatinous foliose and corticate lichenized fungi with transverse septate ascospores were initially grouped in the genus Leptogiopsis by Muller Argoviensis (1882) and subsequently as a section of Leptogium by Vainio (1890). This group now has a total of 11 accepted species, most of them mentioned only by the authors that originally described them.

Leptogium chloromeloides Nyl. was described from Port Natal in South Africa (Nylander 1868); L. thoroldii C.W. Dodge was reported to northern Nigeria and Cameroon (Dodge 1964) and L. ankolense C.W. Dodge from Uganda (Dodge 1971).

In the Americas, Leptogium megapotamicum Malme was described from Brazil (Malme 1924), L. reticulatum Nyl. from French Guiana (Montagne 1841), L. granadillae (C.W. Dodge) Degel. from Costa Rica (Dodge 1933), L. fusisporum (Tuck.) C.W. Dodge from the USA, and $L$. adpressum Nyl. from Mexico, Florida (Sierk 1964) and Africa (Vainio 1901).

Leptogium pacificum Vain. is the only species known from the Philippines (Vainio 1920).

The best known species is L. brebissonii Mont., originally collected in the Canaries Islands (Montagne 1840). It has also been cited for Brazil (Malme 1924), southeast Africa (Swinscow \& Krog 1988), the Iberian Peninsula (Aragon et al. 2005) and New Zealand (Feuerer 2011).

This study describes a new species of section Leptogiopsis sensu Vainio from southeastern Brazil and also provides a detailed description of the type of Leptogium megapotamicum, the nearest species and also from southern Brazil.

This work formed part of a $\mathrm{PhD}$ thesis that described Leptogium types from different morphological groups (Kitaura 2012). 


\section{Materials \& Methods}

The specimens were collected in the cities of Camanducaia, Campos do Jordão, Catas Altas, and Itamonte, all of them localized in the higher regions of the Mantiqueira's Range, a major mountain complex in southeastern Brazil.

A detailed revision of the type of Leptogium megapotamicum (S) was important in order to differentiate the new species.

All specimens were described by our protocol specially developed to analyze Leptogium species (Kitaura 2012, Kitaura \& Marcelli 2012) and the tissues types were classified according Degelius (1954) and Kitaura \& Marcelli (2013).

Leptogium thalli are usually attached by hapters whose presence may produce typical depressions on the upper surface. However, in this group such depressions were not found in all specimens and consequently this characteristic was not included in the descriptions.

\section{Results and Discussion}

Most species of sect. Leptogiopsis are in need of further study. The presence of paraplectenchymatous cortical cells is not a good characteristic for differentiating Leptogium from Collema species (Otálora et al. 2010) and recently Collema species of the C. fasciculare group, also with transverse septate ascospores, were transferred to Arctomia Th. Fr. Otálora \& Wedin (2013) concluded that both have similar characteristics including ascospores, paraphyses, ascus types and hymenial reactions. Thus sect. Leptogiopsis species could also be included in Arctomia.

We have identified at least two Leptogium groups where the general morphology and some anatomical aspects correlate with the presence or absence of the columnar hyphae and with relief of thallus surface (Kitaura 2012). The species with surface weakly ridged to smooth have columnar hyphae and their apothecia have a thick amphithecial tissue, whereas that species with densely ridged surface lack columnar hyphae, but the apothecia have subhymenial paraplectenchymatous tissue and a one-celled layer of amphithecial tissue, as described below.

The apothecial anatomy was critical in establishing the precise circumscription of the species, but it is not fundamental in identification. To the naked eye the type of L. megapotamicum has a smooth to ridged upper surface, as well as inclined columnar hyphae, smooth to verruculose amphithecia and a thick cortex among the amphithecial verrucules, whereas $L$. longisporum has a weakly ridged upper surface to the naked eye, lacks columnar hyphae, has densely ridged, grey amphithecia and thick subhymenial paraplectenchymatous tissue.

Leptogium megapotamicum Malme, Arkiv för Botanik 19(8): 29. 1924.

Figs 1-3

Holotype - Brazil, Rio Grande do Sul State, Municipality of Porto Alegre, Parthenon, corticola in ora Silva, leg. GO Malme 574 (S!).

Etymology - refers to Rio Grande do Sul State (Rio Grande = great river).

Description - Thallus ca. $5 \mathrm{~cm}$ broad, bluish gray under fluorescent light (naked eye), opaque, matt, bluish gray under the stereomicroscope. Branches lobuloid, 1.5-2.5 mm wide, contiguous, adpressed to attached in points, adnate, upper surface smooth to ridged to the naked eye, longitudinal or scattered ridges apparent under 20x magnification; apices rotund to irregular, revolute to ascending, smooth to crenulate; lateral margin smooth to irregular, ascending, sinuous; lower side bluish gray, ridged to the naked eye and under $20 \times$ magnification. Isidia and lobules absent. Thallus attached by hapters; hapters evenly distributed, frequent; rhizines and hairs absent. Apothecia up to $4 \mathrm{~mm}$ diam., marginal to submarginal, subpedicellate, disc cupuliform; margin gray, smooth, without ornamentation; amphithecia gray when young then white or yellowish, smooth and verruculose, verrucules gray; corona discontinuous, slightly evident, on older apothecia; pedicel as ridged as thallus, very short, without ornamentation.

Anatomy - Thallus $125 \mu \mathrm{m}$ thick, $175 \mu \mathrm{m}$ thick on the ridges; quadratic cells of cortices 5 $\mu \mathrm{m}$ wide, columnar hyphae inclined, simple, cell number not determined. Cyanobacteria blue, frequent to sparse, filament of spherical cells of undetermined number, $5 \mu \mathrm{m} \mathrm{diam}$; matrix gelatinous frequent, yellow near to the cortices and hyaline in the mid section. Apothecia with 


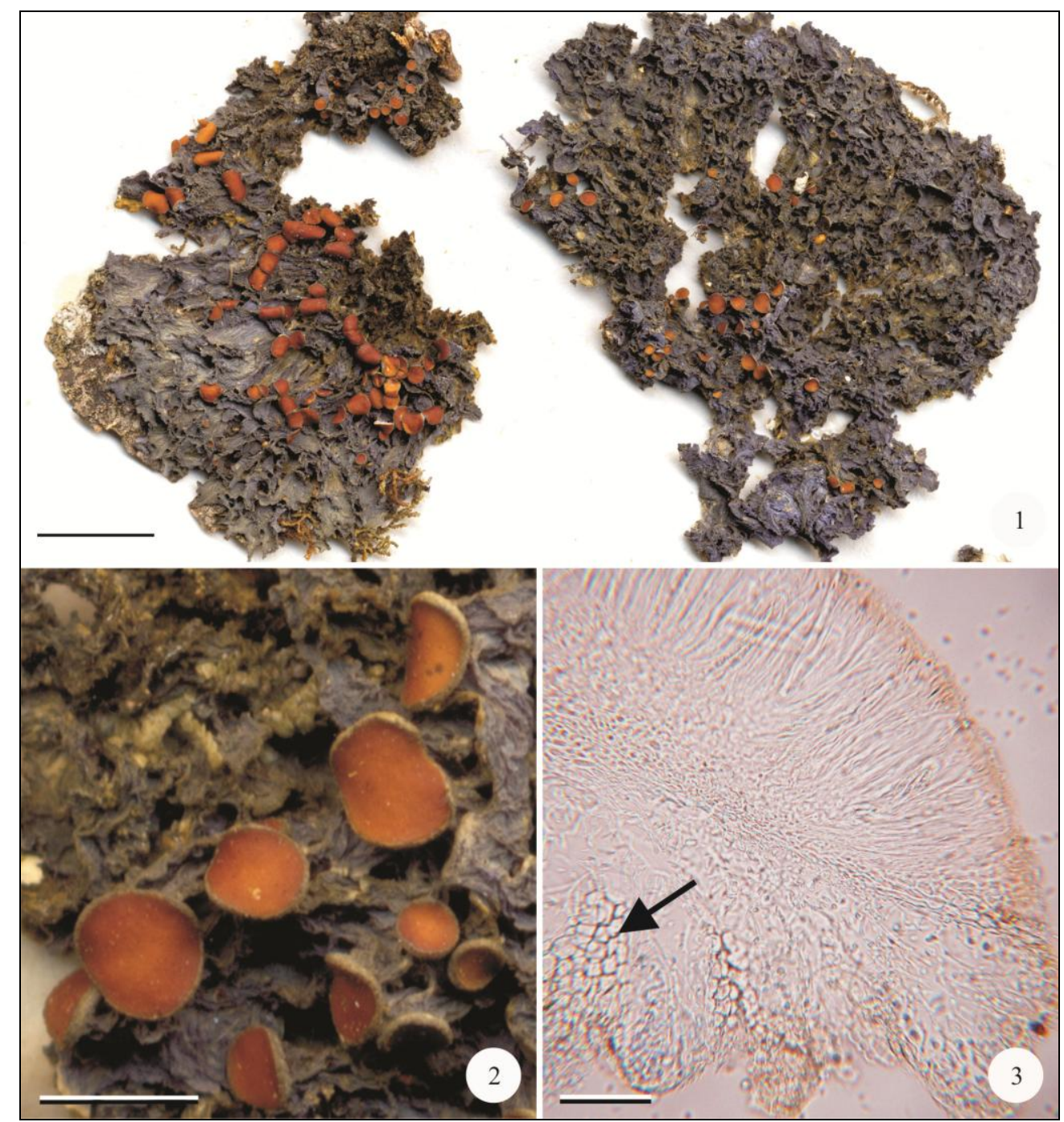

Figs 1-3 - Leptogium megapotamicum. 1 Holotype. 2 Detail of apothecium. 3 Transverse section of apothecia (arrow $=$ thick paraplectenchymatous tissue among the verrucules) - Bars: $1=10 \mathrm{~mm}$, $2=2 \mathrm{~mm}, 3=50 \mu \mathrm{m}$.

hymenia 100-115 $\mu \mathrm{m}$ high, subhymenia $75 \mu \mathrm{m}$ thick, hyaline; hypothecia 20-25 $\mu \mathrm{m}$ thick, prosoplectenchymatous cells, hyaline; subhymenial paraplectenchymatous tissue absent; parahymenial tissue continuous with hypothecium, as high as hymenium, 10-15 $\mu \mathrm{m}$ (3-4 cells) thick at base; 35-40 $\mu \mathrm{m} \quad(4-7$ cells $)$ thick at apex, prosoplectenchymatous to euthyplectenchymatous cells; amphithecia $5 \mu \mathrm{m}$ ( 1 cell $)$ at apex, 5-35 $\mu \mathrm{m}$ (1-5 cells) at middle, 5$100 \mu \mathrm{m}$ (1-8 cells) at base, paraplectenchymatous cells, variable thickness by the presence of verrucules. Ascospores 60-75 $\times 5 \mu \mathrm{m}, 9-12 \times 1$ cells, apices acute, transversely septate. Pycnidia marginal, brown; conidia bifusiform to bacilliform, $3.75 \times 1.25 \mu \mathrm{m}$.

Known distribution - only from the type locality.

Notes - Leptogium megapotamicum is characterized by the ridged upper surface (Fig. 1) and the white to yellowish amphithecia bearing gray verrucules (Fig. 2). The apothecia of $L$. megapotamicum have a prosoplectenchymatous hypothecium and the amphithecia with one to multiple paraplectenchymatous cell layers among the verrucules (Fig. 3).

Malme (1924) described the amphithecia of L. megapotamicum as composed by one layer of cells. However, they are multilayered between the verrucules and this characteristic is important in distinguishing this species. 
Presently, Leptogium megapotamicum appears endemic to the southern-most Brazilian state (Rio Grande do Sul) and has not been found in southeastern Brazil.

Leptogium brebissonii is a somewhat similar species that has isidia and densely grouped ridges (Kitaura 2012), but L. megapotamicum has the upper surface with longitudinal or scattered ridges without isidia.

Leptogium longisporum Kitaura \& Marcelli, sp. nov.

Figs 4-6 MycoBank 804586

Holotype - Brazil, Minas Gerais State, Municipality of Itamonte, near to the road BR-485, on trunk, 22 Nov 2009, leg. M.J. Kitaura \& M.P. Marcelli 1470 (SP).

Etymology - This species has the longest transverse septate ascospores in the genus.

Description - Thallus ca. $5 \mathrm{~cm}$ broad, gray under fluorescent light (naked eye), opaque, matt, gray under the stereomicroscope. Branches lacinioid, $0.7 \mathrm{~mm}$ wide, contiguous to slightly overlapping, attached in points, adnate to ascending, upper surface slightly ridged to the naked eye, densely ridged under $20 \times$ magnification; apices irregular, plane or ascending, ridged or with cerebroid structures; lateral margin usually plane or ascending, with ridged structures; lower side yellowish gray, wrinkled to the naked eye, irregularly ridged under $20 \times$ magnification. Isidia and lobules absent. Thallus attached by frequent, evenly distributed hapters; rhizines and hairs absent. Apothecia up to $4 \mathrm{~mm}$ diam., laminal, subpedicellate, disc usually plane; margin concolorous with the thallus; amphithecium gray, densely ridged (usually cerebroid contorted); corona absent; pedicel very short, densely ridged.

Anatomy - Thallus $150 \mu \mathrm{m}$ thick, $350 \mu \mathrm{m}$ thick at the ridges; quadratic cortical cells $5 \mu \mathrm{m}$ wide, the outer wall thicker than the inner wall; columnar hyphae absent. Cyanobacteria green or bluish, frequent, filaments formed from up to 20 elliptical cells, $5.0 \times 2.5 \mu \mathrm{m}$; gelatinous matrix frequent to abundant, hyaline. Apothecia with hymenia 125-150 $\mu \mathrm{m}$ high, subhymenia $25-65 \mu \mathrm{m}$ thick, hyaline to yellow; hypothecia 25-35 $\mu \mathrm{m}$ thick, yellow, prosoplectenchymatous; subhymenial paraplectenchymatous tissue $75-110 \mu \mathrm{m}(6-11$ cells) thick; parahymenial tissue continuous with subhymenial tissue, colloplectenchymatous, $60-100 \mu \mathrm{m}$ (9-11 cells) thick at base, $40-50 \mu \mathrm{m}$ (710) cells thick at apex, up to $7 / 8$ of hymenium height; amphithecia always $5 \mu \mathrm{m}$ ( 1 cell) thick, the outer wall thicker; basal plectenchymatous tissue absent. Ascospores acicular, 55-90 $\times 5(-7) \mu \mathrm{m}$, 6-11 cells, transverse septate. Pycnidia absent.

Known distribution - Southeastern Brazil, mainly in Minas Gerais and São Paulo States.

Paratypes - Brazil, Minas Gerais State, Municipality of Itamonte, near to the road BR-485, trunk, 22 Nov 2009, leg M.J. Kitaura \& M.P. Marcelli 1503 (SP, topotype), 1522 (SP, topotype); idem, Municipality of Camanducaia, Vila de Monte Verde, 20 Nov 2008, leg. M.P. Kitaura \& M.P. Marcelli 1092 (SP); idem, forest near to the parking area, Pedra Redonda trail, 22 Nov 2008, leg. M.J. Kitaura \& M.P. Marcelli 1239 (SP); idem, Municipality of Lima Duarte, Parque Municipal do Ibitipoca, Serra do Ibitipoca, 1270 m alt., 19 Mar 1994, leg. M.P. Marcelli \& C.H. Ribeiro 26776 (SP); idem, Catas Altas Municipality, Parque Natural do Caraça, Santuário do Caraça, trail to the Cascatinha, 1100 m alt., 06 Jul 1993, leg. M.P. Marcelli \& O. Yano 25932 (SP); idem, São Paulo State, Municipality of Campos do Jordão, Parque Estadual do Jordão, Horto Florestal, trail of Cachoeirinha, 1400 m. alt., 19 Jun 1995, leg. M.P. Marcelli, A.E Luchi \& A.M. Gugliotta 29091 (SP).

Notes -Leptogium longisporum is characterized by the lacinioid branches whose upper surface has dense ridges bearing cerebroid structures at the apices. The apothecia have a thick subhymenial paraplectenchymatous tissue and the acicular ascospores, 55-90 $\times 5(-7) \mu \mathrm{m}$, are the longest among the species with transverse septa.

Leptogium longisporum was collected in the Serra da Mantiqueira and initially identified as L. megapotamicum since the specimens agree well with the protologue (Malme 1924). However, a detailed morphological and anatomical study revealed several significant differences between these non-isidiate species. 


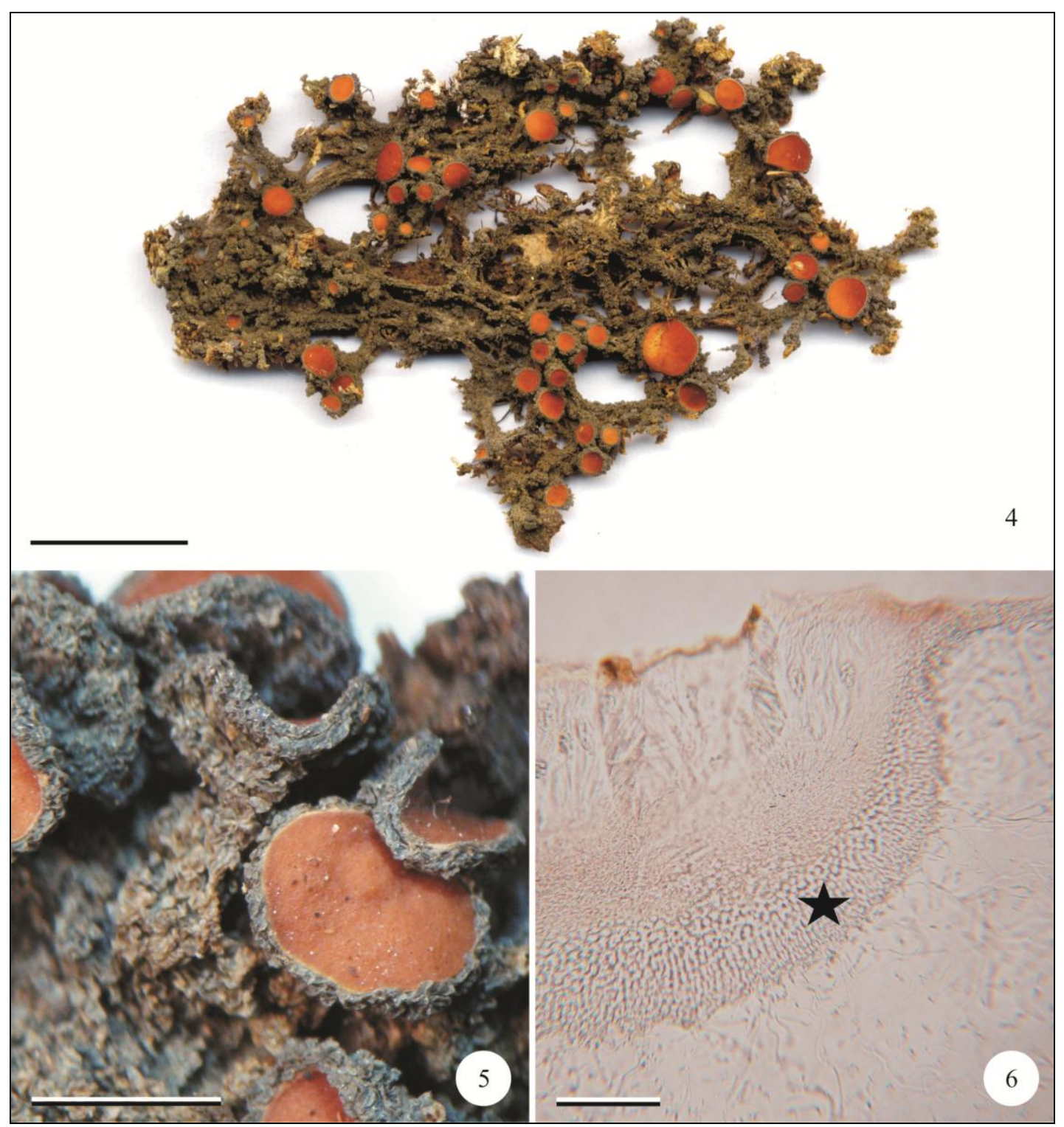

Figs 4-6 - Leptogium longisporum. 4 Holotype. 5 Detail of apothecium. 6 Transverse section of apothecium ( $\mathrm{star}=$ subhymenial paraplectenchymatous tissue). - Bars: $4=2 \mathrm{~cm} ; 5=2 \mathrm{~mm} ; 6=50$ $\mu \mathrm{m}$.

Subhymenial tissue composed of paraplectenchymatous cells was observed in several Leptogium species by Malme (1924), who mentioned it as "strato parenchymatico sub hypothecio", and its presence or absence has been considered an important taxonomic characteristic for distinguishing Leptogium species (Swinscow \& Krog 1988). However, Malme described L. megapotamicum as lacking such tissue but with amphithecia composed by a simple layer of cells.

The absence of a thick paraplectenchymatous tissue in the apothecia of Leptogium species is not common, and we initially believed that Malme may have been mistaken. However, sections of the apothecium of the type of L. megapotamicum were made and Malme's observations confirmed.

The apothecia of_Leptogium longisporum differs anatomically from both L. megapotamicum and L. fusisporum. Leptogium longisporum has a thick subhymenial paraplectenchymatous tissue and a one-layered amphithecium whereas L. megapotamicum and L. fusisporum lack subhymenial paraplectechyma tissue, but have a paraplectenchymatous multilayered amphithecium instead.

The cerebroid structures present on the apices of the thallus ridges are somewhat similar to those found in L. microcarpum, but that species does not have transverse septate spores (Kitaura 2012). 


\section{Key to Brazilian species of Leptogium species with transverse septate ascospores}

1. Isidia present. Leptogium brebissonii Mont.

1. Isidia absent 2

2. Upper surface smooth to ridged to the naked eye, the ridge apices not ornamented; the amphithecia verruculose with thick paraplectenchymatous tissue between the verrucules; subhymenial paraplectenchymatous tissue absent ................Leptogium megapotamicum Malme 2. Upper surface slightly ridged to the naked eye; ridges ornamented with cerebroid structures; the amphithecia ridged and totally covered with a thin paraplectenchymatous tissue (one layer); a thick subhymenial paraplectenchymatous tissue present........Leptogium longisporum Kitaura \& Marcelli

\section{Acknowledgements}

The authors wish to thank Dr. Jack Elix for the revision of the English text, Dr. Arne Anderberg and Dr. Marianne Hamnede (S) for the loan of the type of Leptogium megapotamicum, and an unknown assessor for valuable suggestions. M.J. Kitaura wishes to thank the FAPESP (2008/51072-3) for a PhD grant and M.P. Marcelli, CNPq for a research grant.

\section{References}

Aragón G, Otálora MAG, Martínez I. 2005 - New data on the genus Leptogium (lichenized ascomycetes) in the Iberian Peninsula. Nova Hedwigia 80(1-2), 199-226.

Degelius G. 1954 - The lichen genus Collema in Europa. Symbolae Botanicae Upsalienses 13(2), $1-499$.

Dodge CW. 1933 - The foliose and fruticose lichens of Costa Rica I. Annals of the Missouri Botanical Garden 20, 373-467.

Dodge CW. 1964 - Some lichens of Tropical Africa. Nova Hedwigia 12, 118-131.

Dodge CW. 1971 - Some lichens of Tropical Africa. V. Lecanoraceae to Physciaceae. Nova Hedwigia 38, 1-225.

Feuerer T. 2011 - Biodiversity of lichens and licheniculous fungi [Internet]. Version 1 August 2011. Available: http://webapp5.rrz.uni-hamburg.de/lichens/formular.php (accessed 2013 Feb 21).

Kitaura MJ. 2012 - Estudos taxonômicos de Leptogium (Ach.) S.F. Gray (Collemataceae, fungos liquenizados) [thesis]. Instituto de Biociências, UNESP, Universidade Estadual Paulista, Botucatu. 249 p.

Kitaura MJ, Marcelli MP. 2012 - The Leptogium juressianum complex in southeastern Brazil. Mycotaxon 120, 215-221.

Kitaura MJ, Marcelli MP. 2013 - A revision of Leptogium species with spherical-celled hairs (section Mallotium p.p.). The Bryologist 116(1), 15-27.

Malme GOA. 1924 - Die Collematazeen dês Regnellschen Herbars. Arkiv för Botanik 19(8), 1-29.

Montagne JFC. 1840 - Phytographia Canariensis, sectio ultima, Plantas cellulares sistens. In: Webb PB, Berthelot S, editors. Histoire Naturelle des Canaries III, Paris.

Montagne JFC. 1841 - Seconde centurie de plantes cellulaires exotiques nouvelles, Décade IX. Annales des Sciences Naturelles 16, 108-128.

Müller Argoviensis J. 1882 - Lichenologische Beiträge. Flora oder Allgemeine Botanische Zeitung (Jena) 65(19), 291-306.

Nylander W. 1868 - Note sur les lichens de Port-Natal. Bulletin de la Societe Linneenne de Normandie 3, 4-15.

Otálora MAG, Aragón G, Molina MC, Martínez I, Lutzoni F. 2010 - Disentangling the CollemaLeptogium complex through a molecular phylogenetic study of the Collemataceae (Peltigerales, lichen-forming Ascomycota). Mycologia 102(2), 279-290.

Otálora MAG, Wedin M. 2013 -Collema fasciculare belongs in Arctomiaceae. The Lichenologist 45(2), 1-10. 
Sierk HA. 1964 - The genus Leptogium in North America North of Mexico. The Bryologist 67(3), 245-317.

Swinscow TDV, Krog H. 1988 - Macrolichens of East Africa, British Museum (Natural History). London.

Vainio EA. 1890 - Étude sur la classificationnaturalle et la morphologie des lichens du Brésil. Acta Societatis pro Fauna Flora Fennica 7. Helsingfors.

Vainio EA. 1901 - Lichenes; Catalogue of the African plants collected by Dr. Friedrich Welwitsch in 1853-61. Vol. II. Part II. pp. 396-493. Cryptogamia. London.

Vainio EA. 1920 - Lichenes Insularum Philippinarum III. Annales Academiae Scientiarum Fennicae 15, 1-368. 